\title{
HISTORIE A SOUČASNOST REYOVA AUDITORNĚ-VERBÁLNÍHO TESTU UČENÍ (RAVLT) V ČESKU
}

\author{
Zuzana Frydrychová \& Hana Georgi
}

\begin{abstract}
Abstrakt
Problematika učení a zapomínání je předmětem systematického zkoumání již od konce 19. století. Od učení bezesmyslného materiálu se později přešlo ke zkoumání paměti pomocí materiálu smysluplného a v této tradici se pokračuje doposud. I přes postupný vývoj poznání a nových metod pro zkoumání paměti se pro tyto účely stále nejčastěji užívají testy seznamů slov. Vůbec prvním takovým testem, který je dodnes užíván, byl Test paměti na slova, známý pod názvem Reyův auditorně-verbální test učení (RAVLT). Metoda přispěním několika autorů postupně nabyla dnešní podoby, která kromě pokusů učení zahrnuje administraci seznamu B (interference), oddálené vybavení a rekognice. V současnosti se jedná o jednu z nejvíce používaných metod pro měření verbální paměti.

V Česku jsou dostupné dvě verze RAVLT, starší známá pod názvem Pamětový test učení, a druhá, jejíž překlad se více přiblížil původní anglické verzi. Cílem př́spěvku je poskytnout přehled historie a dosavadního vývoje RAVLT v Česku, popsat klinickou a výzkumnou užitečnost této metody zejména u populace starších osob a v neposlední řadě představit možnosti jejího využití do budoucna.
\end{abstract}

Klíčová slova: epizodická pamět'; historie; test seznamů slov

\section{HISTORY AND PRESENT OF REY AUDITORY-VERBAL LEARNING TEST (RAVLT) IN THE CZECH REPUBLIC}

\begin{abstract}
Learning and forgetting has been the subject of systematic research since the late $19^{\text {th }}$ century. The examination of memory was through the meaningless syllables at the beginning, which was later replaced with meaningful material, and this tradition continues until now. Despite of the development of knowledge and new methods for testing memory, word list tests are still the most commonly used for these purposes. The first such test, which is still currently used, was Test of memory for words known as Rey Auditory-Verbal Learning Test (RAVLT). Thanks to the contribution of some authors, the method gained its current form and besides the learning trials includes administration of the list $B$ (interference), delayed recall and recognition. Currently, it is one of the most used methods for examination of verbal memory.

There are available two versions of RAVLT in the Czech Republic, older known as the "Pamétový test učeni", and the second one, which translation is more adequate to the English version. The aim of the paper is to provide an overview of the history and current development of RAVLT in the Czech Republic, to describe the clinical and research usefulness of this method especially in the elderly population and to present possibilities of its use in the future.
\end{abstract}

Keywords: episodic memory; history; word list test

Došlo: 9. 12. 2018

Schváleno: 29. 1. 2019 


\section{Úvod}

Systematické zkoumání problematiky učení a zapomínání datujeme od prací Hermanna Ebbinghause (1885) zaměřených na učení seznamu bezesmyslných slabik (Bower, 2000). Již Ebbinghausovy experimenty ukázaly, že učení je závislé na typu učeného materiálu, jelikož i u bezesmyslných slabik je přirozenou tendencí je sémanticky kódovat (napřr. v angličtině bezesmyslná slabika MIK je překódována na „MIKE s chybějícím E“). Tato zjištění vedla na konci šedesátých let v praxi k oslabení používání bezesmyslných materiálů pro účely zkoumání verbální paměti a přistoupilo se k uživání materiálu smysluplného (slova, věty, př́iběh, obrázky atd.) (Bower, 2000). V současnosti se v této tradici pokračuje a při zkoumání zmíněné problematiky jsou využívány především testy seznamů slov, jejichž počátek sahá již do 19. století, kdy Binet a Henri (1894) publikovali několik experimentů zkoumajících pamět' prostřednictvím seznamů slov (Griffin et al., 2017). Jednotlivé metody používané pro tyto účely se mohou lišit ve způsobu administrace jednotlivých fází, což je přehledně zobrazeno v tabulce č. 1 .

Tabulka č. 1: Způsoby testování verbální epizodické paměti

\begin{tabular}{|c|c|c|c|}
\hline Fáze & Způsob & Příklady & Př́́klady metod \\
\hline \multirow[t]{2}{*}{ Prezentace } & Auditorní & $\begin{array}{l}\text { a) Slova bez vzájemného } \\
\text { sémantického vztahu, } \\
\text { b) Slova se vzájemným } \\
\text { sémantickým vztahem, } \\
\text { c) Ucelený př́běh }\end{array}$ & $\begin{array}{l}\text { a) RAVLT, } \\
\text { b) CVLT-II, PVLT, } \\
\text { c) Logická pamět' } \\
\text { (WMS-III) }\end{array}$ \\
\hline & Vizuální & $\begin{array}{l}\text { a) Obrázky, } \\
\text { b) Text (slova, příběh, } \\
\text { věta) }\end{array}$ & $\begin{array}{l}\text { a) FCSRT, } \\
\text { b) DRS-2 (Pamět'), } \\
\text { c) Memory Binding Test }\end{array}$ \\
\hline \multirow{3}{*}{ Kódování } & $\begin{array}{c}\text { Akustické } \\
\text { (fonologické) }\end{array}$ & $\begin{array}{l}\text { a) Slova bez vzájemného } \\
\text { sémantického vztahu }\end{array}$ & a) RAVLT \\
\hline & $\begin{array}{l}\text { Akusticko- } \\
\text { sémantické }\end{array}$ & $\begin{array}{l}\text { a) Slova se vzájemným } \\
\text { sémantickým vztahem, } \\
\text { b) Ucelený př́iběh }\end{array}$ & $\begin{array}{l}\text { a) CVLT-II, PVLT, } \\
\text { b) Logická pamět' } \\
\text { (WMS-III) }\end{array}$ \\
\hline & $\begin{array}{l}\text { Vizuálně- } \\
\text { sémantické } \\
\text { (ikonické) }\end{array}$ & $\begin{array}{l}\text { a) Obrázky }+ \\
\text { pojmenování, } \\
\text { b) Text }+ \text { přečtení }\end{array}$ & $\begin{array}{l}\text { a) FCSRT, } \\
\text { b) DRS-2 (Pamět') }\end{array}$ \\
\hline \multirow[t]{2}{*}{ Vybavení } & Orální & $\begin{array}{l}\text { a) Volné vybavení bez } \\
\text { nápovědy, } \\
\text { b) Volné vybavení + } \\
\text { vybavení s nápovědou }\end{array}$ & $\begin{array}{l}\text { a) RAVLT, } \\
\text { b) Logická pamět' } \\
\text { (WMS-III) } \\
\text { c) PVLT }\end{array}$ \\
\hline & Písemné & a) Volné vybavení & $\begin{array}{l}\text { a) Např.: při skupinové } \\
\text { administraci }\end{array}$ \\
\hline Rekognice & Orální & $\begin{array}{l}\text { a) Výběr ze dvou či více } \\
\text { možností, seznam } \\
\text { cílových slov a } \\
\text { distraktorů (ANO/NE), }\end{array}$ & $\begin{array}{l}\text { a) RAVLT, } \\
\text { b) PVLT }\end{array}$ \\
\hline
\end{tabular}




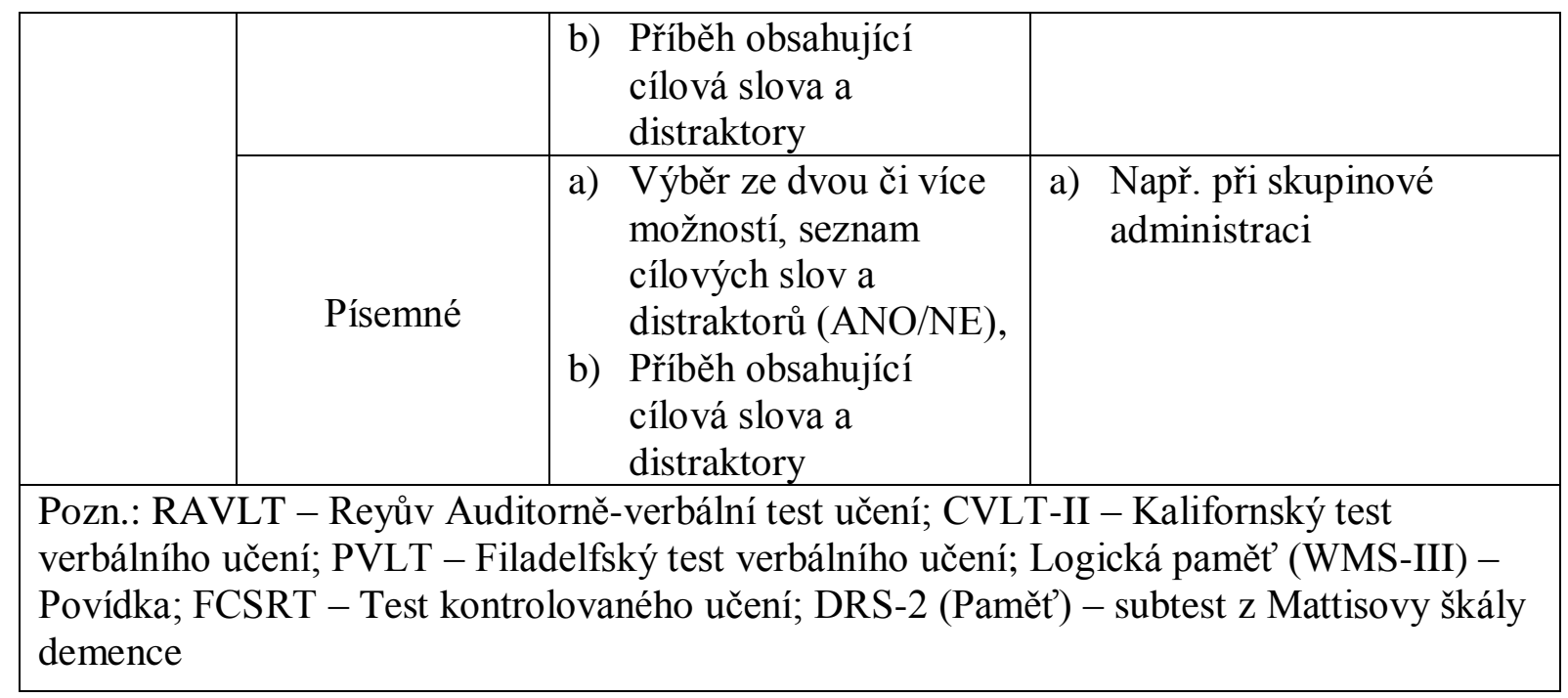

Testy seznamů slov se liší mírou, do jaké je podnětový materiál logicky uspořádán. Testy obsahující slova bez zjevného sémantického vztahu (např. RAVLT) jsou náročnější, jelikož pro jejich zapamatování a volné vybavení je potřeba vynaložit větší úsilí než u testů, ve kterých spolu slova vzájemně sémanticky souvisí (např. PVLT, CVLT-II), či je podnětový materiál prezentován formou př́běhu (napřr. Logická pamět' (WMS-III) - Povídka) (Strauss, Sherman, Spreen, \& Spreen, 2006).

\section{Cíl studie}

Cílem studie je souhrnně představit historický vývoj jednoho z nejčastěji použivaných a nejstarších testů seznamů slov - Reyova Auditorně-verbálního testu učení (RAVLT) v Česku, ale i v zahraničí, srovnání seznamů slov (originální francouzská verze, anglická adaptace a české verze), klinickou a výzkumnou užitečnost této metody u populace starších osob. V neposlední řadě jsou představeny implikace pro klinickou praxi a návrhy pro zaměření budoucího výzkumu.

\section{Historie metody v zahraničí}

Test paměti na slova ( $\mathrm{z}$ francouzského originálu „Test de mémoire des mots“) vyvinutý Édouardem Claparèdem (1919) sestával ze seznamu 15 podnětových slov bez zjevného sémantického vztahu (seznam A) administrovaných $\mathrm{v}$ jednom pokusu prezentace a volného vybavení, včetně dvou alternativních seznamů slov (seznam B a C) o přibližně stejné obtížnosti jako slova ze seznamu A. Tento test se objevil v kompendiu Otto Lipmanna (1922), ve kterém představoval psychologické nástroje pro psychiatrickou diagnostiku. Později byla tato metoda rozpracována André Reyem (1958), Claparèdovým doktorandem, který ji nazval Memorizace seznamu 15 slov v 5 opakováních (z francouzského originálu „Mémorisation d'une série de 15 mots en 5 répétitions“). Rey takto upravenou metodu poprvé představil v roce 1941 a později (1958) publikoval její manuál včetně čtvrtého alternativního seznamu D. Originální Claparèdovu techniku rozšíril na 5 pokusů volného vybavení (seznam A), a přidal rekognici ve formě příběhu obsahujícího 30 podstatných jmen - 15 cílových slov a 15 distraktorů. Ve stejné publikaci uvedl i průměrné skóry pro jednotlivé pokusy a percentilové normy pro 
součet pokusů volného vybavení a rekognici pro děti, mladší a starší dospělé členěné dle vzdělání.

Původní francouzská verze testu byla do angličtiny adaptována Edith M. Taylorovou (1959) a pojmenována Auditorně-verbální test učení (z anglického originálu „Auditory-Verbal Learning Test"). Taylorová při adaptaci metody zachovala dva původní seznamy $\mathrm{A}$ a $\mathrm{B}$, zbylé dva alternativní (C a D) nebyly do angličtiny adaptovány. Do administrace metody navíc zahrnula proaktivní interferenci (přeložený a upravený originální seznam B od Claparèdea), retroaktivní interferenci (pokus 6 - volné vybavení seznamu A) a oddálené volné vybavení (seznam A) po 30 minutách (Lezak, Howieson, Bigler, \& Tranel, 2012; Mitrushina, Boone, Razani, \& D'Elia, 2005). V USA test významně zpopularizovala Muriel D. Lezaková v prvním vydání publikace Neuropsychological Assessment z roku 1976 (podle Hess, 2007). Lezaková (1976) rovněž standardizovala administraci metody a publikovala alternativní seznam slov lišící se od původních francouzských alternativ, který může $\mathrm{v}$ případě opakovaného měření nahradit seznam A či B.

V současnosti je metoda známa jako Reyův auditorně-verbální test učení (RAVLT) či zkráceně Auditorně-verbální test učení (AVLT) (Boake, 2000; Cavaco et al., 2015; Lezak et al., 2012). Existují různé verze RAVLT lišící se v podnětových slovech. Liší se i způsoby administrace a prezentace slov ( 1 slovo/1 vteřinu vs. jednovteřinový interval mezi slovy atd.). Zároveň jsou publikovány i odlišné formy rekognice (seznam slov, prríběh, či nucený výběr ze dvou či více možností). Nicméně nejčastěji používanou formou administrace je ta od Lezakové (2012), která je podrobně popsaná i jinde (Bezdicek, Stepankova, et al., 2014b; Frydrychová, Kopeček, Bezdíček, \& Štěpánková Georgi, 2018; Preiss et al., 2012).

\section{Historie metody v Česku}

V České republice byly vydány dvě verze RAVLT: první Pamětový test učení (Preiss, 1994) a druhá v revidovaném překladu Bezdička, Štěpánkové a Nikolaie (2014c) Reyův auditorněverbální test učení ${ }^{1}$.

Preiss (1994) publikoval český překlad RAVLT (seznam A a B) pod názvem „Pamětový test učení“ (PTU) a v roce 1999 vydal český manuál k této metodě. Existují české normy PTU pro děti ve věku 9 až 14 let (dle věku a pohlaví; Preiss, Motejlková, Janů, \& Kolářová, 2001) a dospělé od 20 do 85 let (dle věku a vzdělání; Bezdicek, Stepankova et al., 2014b). Na tyto normy, vzhledem k velikosti skupin starších dospělých (nad 50 let), lze pohlížet jako na pilotní. Později bylo přistoupeno k revizi českého přkladu pro několik důvodů týkajících se obsahové validity RAVLT (Bezdíček et al., 2014c). Detailněji je revize a srovnání českých verzí seznamů slov představeno níže. Revidované seznamy včetně rekognice pak byly publikovány Horákovou a kol. (2016) a záznamové archy včetně instrukcí jsou aktuálně dostupné na internetových stránkách Národního ústavu duševního zdraví (NUDZ)². Vzhledem k tomu, že je RAVLT používán často u starších osob v rámci neuropsychologické diagnostiky, je zapotřebí disponovat robustními a reprezentativními českými normami pro tuto populaci, což ty původní pro starší verzi testu (Bezdicek, Stepankova, et al., 2014b) nesplňovaly. Z tohoto důvodu byly

\footnotetext{
${ }^{1} \mathrm{~V}$ česky psané odborné literatuře se lze setkat s pojmy „auditorní“ $\mathrm{i}$ „auditivní“.

${ }^{2}$ http://www.nudz.cz/files/pdf/ravlt_instrukce_skorovani.pdf
} 
mj. vytvořeny nové normy (Frydrychová et al., 2018) pro osoby ve věku 60 a více let stratifikované dle věku a vzdělání včetně regresních rovnic zohledňujících věk, vzdělání a pohlaví. Pro výpočet T-skórů, Z-skórů a percentilů pro všechny pokusy volného vybavení a rekognici je možné bezplatně využít software Kognitivní kalkulátor (KoKa - Kognitivní kalkulátor, 2018), který je dostupný na stránkách NUDZ³ .

\section{Srovnání verzí RAVLT}

V tabulce č. 2 (pro svůj formát je zařazena na konec článku) jsou přehledně uvedeny podnětové seznamy výše zmiňovaných verzí RAVLT (seznam A a B) - originální Claparèdův seznam ve francouzském jazyce (1919), jeho doslovný překlad do anglického jazyka (Boake, 2000), anglická adaptace Edith M. Taylorové (1959) a obě české verze (Bezdíček et al., 2014c; Preiss, 1994).

Z tabulky č. 2 je patrné, že seznamy slov (A a B) prošly určitým vývojem, při překladu a adaptaci došlo ke změně některých slov. Taylorová (1959) zaměnila některá slova z původního seznamu (např.: ,sun“ za „moon“; označeno tučně). Stejně tak došlo při překladu z angličtiny do češtiny (Preiss, 1994) k záměně některých slov (např.: „turkey“ zaměněno za „Čína“) a použití množného čísla oproti jednotnému (např.: „cloud“ přeloženo jako „mraky“) tak, jak je to v původních verzích (označeno kurzívou). Pro dosažení vyšší obsahové validity české verze byla provedena revize českých seznamů slov (Bezdíček et al., 2014c), při které bylo dosaženo vyšší sémantické ekvivalence (např. „Čína“ nahrazena slovem „husa“), dále byly výrazy hovorové češtiny nahrazeny spisovnými („kafe“ vs. „káva“), byla vyřazena propria, jako je geonymum „Č́na“" ve prospěch apelativ, protože seznam se skládá pouze z obecných jmen a v neposlední řadě došlo k oslabení efektu slovní délky (,zemědělec“ nahrazen ,sedlákem“) pro vyšší homogenitu seznamů.

Obě české verze se průměrným počtem slabik na jedno slovo přibližují spíše francouzské verzi testu než anglickému překladu či adaptaci od Taylorové. To je dáno především tím, že v anglické adaptaci jsou použita slova maximálně dvouslabičná, avšak v obou českých překladech se vyskytují i slova tř́slabičná (např.: záclona, zahrada), a ve verzi Preisse (1994) dokonce i jedno čtyřslabičné (zemědělec). Přestože se jedná o běžně používaná slova v českém jazyce, může se projevit efekt délky slov a ztížit tak jejich zapamatování.

\section{Klinické a výzkumné využití RAVLT}

Metoda RAVLT poskytuje množství informací o procesu učení a verbální epizodické paměti bezprostřední a krátkodobé. Proto je často zařazována jako součást fixních či flexibilních neuropsychologických baterií při diagnostice kognitivního deficitu zejména u starších osob. Tato metoda je užitečná především v prodromálních či preklinických stádiích neurodegenerativních onemocnění, naopak v pozdějších stádiích už pozbývá smyslu vzhledem k její náročnosti (Nikolai, Vyhnálek, Štěpánková \& Horáková, 2013, s. 23).

\footnotetext{
${ }^{3}$ http://www.nudz.cz/p_skupina/ps-geropsychologie/
} 
Výkon v testu RAVLT může být ovlivněn různými situačními vlivy, ale i socio-kulturními či výběrem osob do dané studie. To dokumentují následující př́íklady.

Průměrný výkon osob ve věku 50 až 65 let v oddáleném volném vybavení byl v české studii 11 slov (Bezdicek, Stepankova, et al., 2014b), oproti tomu americké normy udávají průměrný výkon osob v této věkové skupině 9 slov (Harrison, Weintraub, Mesulam, \& Rogalski, 2012; Schmidt, 2004). Rozdíl může být dán náborem a zařazením osob z kurzů univerzit třetího věku do české studie, jejichž výkon může být nadprůměrný. Avšak jak je zřejmé z tabulky č. 3, i průměrný výkon i u mladších dospělých se může lišit mezi jednotlivými normativními studiemi realizovanými v různých zemích (Bezdicek, Stepankova, et al., 2014b; Ferreira Correia \& Campagna Osorio, 2014; Messinis, Tsakona, Malefaki, \& Papathanasopoulos, 2007; Poreh, Sultan, \& Levin, 2012). Tyto rozdílné průměrné výkony mezi jednotlivými zeměmi tak jen ukazují důležitost disponovat adekvátními normami pro dané socio-kulturní prostředí, jak zmiňuje i Jolana Stehlíková (2018) ve své recenzi Pamětového testu učení (tj. metody M. Preisse). Zajímavé je, že aktuálnější české normy RAVLT pro populaci starších osob (Frydrychová et al., 2018) prezentují shodně s americkými normami (Harrison et al., 2012; Schmidt, 2004) průměrný výkon osob ve věku 60 až 75 let 9 slov v oddáleném vybavení RAVLT, což je zároveň i průměrný skór pro tuto věkovou kohortu v české verzi Filadelfského testu verbálního učení (PVLT; Bezdicek, Libon, et al., 2014a). Test PVLT obsahuje oproti RAVLT pouze 12 podnětových slov celkem ze tří sémantických kategorií. Zdá se tedy, že 9 slov je pro mladší seniory normální výkon oddáleného vybavení u různých testů seznamů slov s počtem podnětů nad oněch 9 .

Tabulka č. 3: Průměrné skóry v oddáleném volném vybavení u dospělých osob

\begin{tabular}{|l|l|l|l|}
\hline \multicolumn{1}{|c|}{ Autoři (rok) } & \multicolumn{1}{|c|}{ Stát } & Věk & $\begin{array}{l}\text { Vzdělání: průměrný skór } \\
\text { v oddáleném vybavení }\end{array}$ \\
\hline Ferreira Correia a kol. (2014) & Venezuela & $20-49$ & $\begin{array}{l}0-3 \text { roky: } 12,4 \\
4-12 \text { let: } 13,8 \\
13 \text { a více let: } 14,1\end{array}$ \\
\hline Messinis a kol. (2007) & Řecko & $19-39$ & $\begin{array}{l}1-9 \text { let: } 10,7 \\
10-12 \text { let: } 11,1 \\
13-21 \text { let: } 10,9\end{array}$ \\
\hline Bezdicek a kol. (2014b) & Česko & $20-34$ & $\begin{array}{l}12 \text { či méně let: } 11,9 \\
13 \text { a více let: } 12,6 \\
\text { všichni: } 12,36\end{array}$ \\
\hline Poreh a kol. (2012) & Omán & $21-30$ & $\begin{array}{l}\text { nižší: } 10,8 \\
\text { vyšší: } 11,2\end{array}$ \\
\hline
\end{tabular}


V klinické praxi pak bývají nejčastěji interpretovány základní skóry RAVLT a křivka učení značící schopnost jedince naučit se verbální materiál. Její profil (graf č. 1) je společně s oddáleným vybavením (T8), procentem zapomínání (poměr mezi T5 a T8) a množstvím slov naučených v průběhu pěti pokusů (součet volně vybavených slov v pokusech T1 až T5) vodítkem pro odlišení normálního stárnutí od patologického stárnutí reprezentovaného amnestickou formou mírné kognitivní poruchy (a-MCI) či demencí Alzheimerova typu (AD) (Estévez-González, Kulisevsky, Boltes, Otermín, \& García-Sánchez, 2003). Mezi typické znaky výkonů v RAVLT při Alzheimerově nemoci patří (Nikolai et al., 2013):

- $\quad$ Nízký skór bezprostředního vybavení

- Plochá či kolísavá křivka učení

- Výskyt konfabulací

- $\quad$ Oddálené vybavení s poklesem oproti bezprostřednímu

- Chyby v rekognici (nepoznává cílové podněty, chybně označuje ne-cíle)

Graf č. 1: Př́iklady křivek učení a rekognice - normální, amnestická forma mírné kognitivní poruchy (a-MCI) a mírná/lehká demence u Alzheimerovy nemoci (AD)

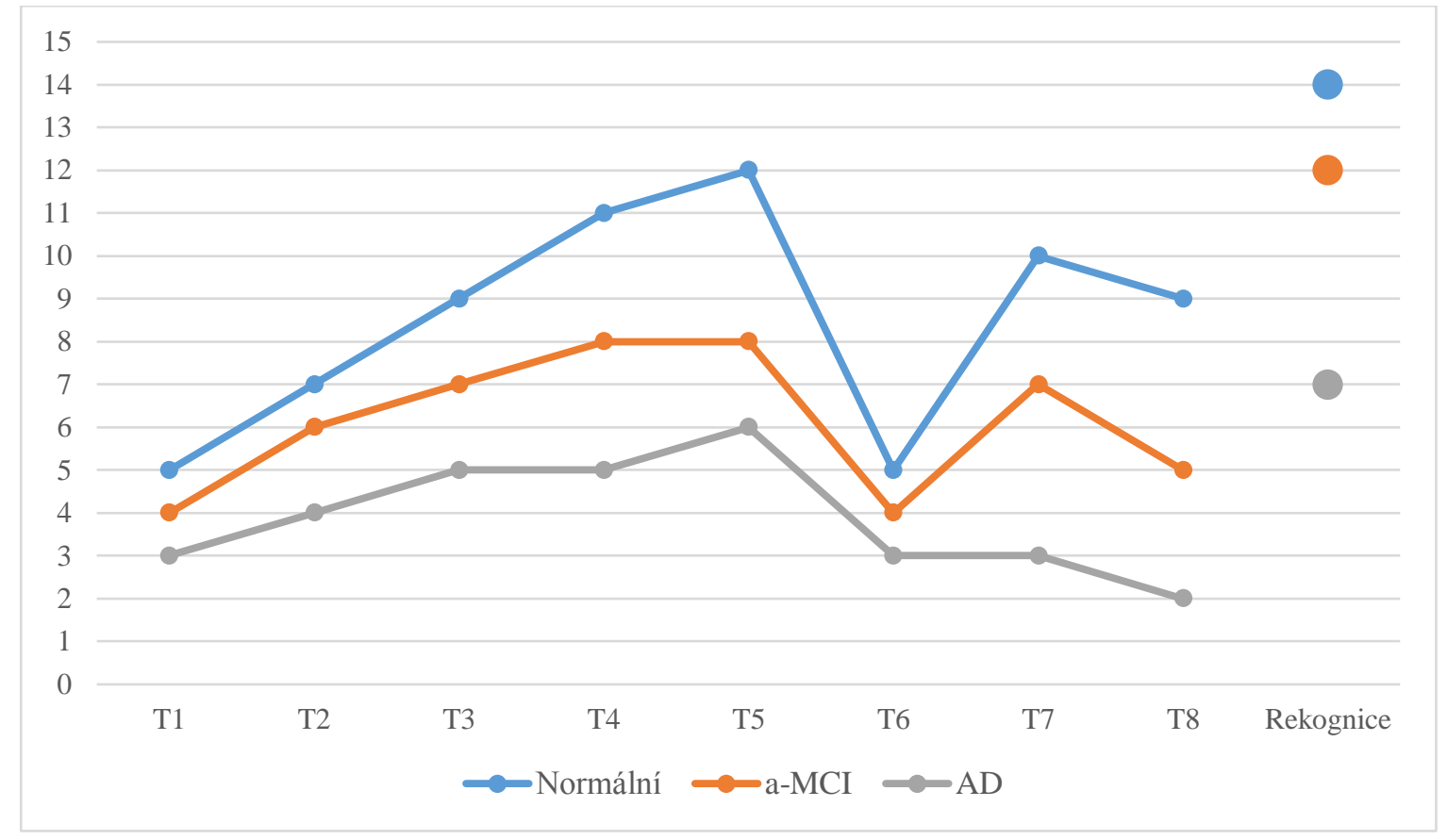

Ze zmiňovaných základních skórů RAVLT lze dopočítat i další odvozené skóry, které je možné interpretovat (např. procento zapomínání, proaktivní a retroaktivní interferenci). Tyto skóry nebývají tak často používány v klinické praxi jako ve výzkumu. Výzkumné využití RAVLT nemusí být jen v oblasti stárnutí spojeného s patologickým poklesem kognice. Tento nástroj lze považovat za užitečný při určování tzv. „memory superagers“, což jsou osoby nad 80 let, jejichž výkon v testu měřícím epizodickou pamět' je stejný či lepší než průměrný výkon mladších seniorů (tj. 9 a více slov v oddáleném volném vybavení) (Červenková, Heissler, Georgi, \& Kopeček, 2018; Harrison et al., 2012). 


\section{Závěr}

Test paměti na slova, respektive jeho modifikace RAVLT, je jediným dosud používaným testem v klinické praxi obsažených v Lipmannově kompendiu (1922), což z něj činí jednu z nejstarších kontinuálně používaných psychologických metod (Boake, 2000). V zahraničí je RAVLT jedním z nejužívanějších testů pro měření verbální paměti a desátou nejčastěji administrovanou neuropsychologickou metodou (Rabin, Barr, \& Burton, 2005). Rovněž v České republice je RAVLT jedním z nejvíce rozšiřrených testů a je doporučovanou metodou pro klinickou praxi (Horáková et al., 2017; Nikolai et al., 2016; Preiss et al., 2012) pro svou jednoduchost a rychlost administrace, jako i pro jeho klinickou užitečnost a psychometrické vlastnosti (senzitivita a specifita) (Britt, Adams, Godding, Grothues, \& Varnado, 1995; Cerami et al., 2017; Ricci, Graef, Blundo, \& Miller, 2012).

I přesto v současné době chybí studie realizovaná na české populaci, která by ověřovala psychometrické vlastnosti (validita, specificita a senzitivita) metody RAVLT. Stejně tak chybí podrobná analýza z lingvistického pohledu zaměřující se na efekt pořadí slov na zapamatování a jeho př́ípadnou souvislost s frekvencí výskytu slov v českém jazyce.

\section{Poděkování}

Studie vznikla s podporou projektu „Kognitivní superaging“, GAČR 18-06199S a projektu „Udržitelnost pro Národní ústav duševního zdraví“, č. LO1611, za finanční podpory MŠMT v rámci Národního programu udržitelnosti I (NPU I).

\section{Literatura}

Bezdicek, O., Libon, D. J., Stepankova, H., Panenkova, E., Lukavsky, J., Garrett, K. D., ... Kopecek, M. (2014a). Development, validity, and normative data study for the 12-Word Philadelphia Verbal Learning Test [czP(r)VLT-12] among older and very old Czech adults. The Clinical Neuropsychologist, 28(7), 1162-1181. https://doi.org/10.1080/13854046.2014.952666

Bezdicek, O., Stepankova, H., Moták, L., Axelrod, B. N., Woodard, J. L., Preiss, M., ... Poreh, A. (2014b). Czech version of Rey Auditory Verbal Learning test: Normative data. Aging, Neuropsychology, and Cognition, 21(6), 693-721. https://doi.org/10.1080/13825585.2013.865699

Bezdíček, O., Štěpánková, H., \& Nikolai, T. (2014c). RAVLT - revidovaný Reyův auditorněverbální test učení. Získáno z http://www.nudz.cz/files/pdf/ravlt_instrukce_skorovani.pdf

Binet, A., \& Henri, V. (1894). Mémoire des mots. L'année psychologique, 1(1), 1-23. https://doi.org/10.3406/psy.1894.1044

Boake, C. (2000). Edouard Claparède and the Auditory Verbal Learning Test. Journal of Clinical and Experimental Neuropsychology (Neuropsychology, Development and Cognition: Section A), 22(2), 286-292. https://doi.org/10.1076/1380-3395(200004)22:2;1$1 ; \mathrm{FT} 286$

Bower, G. H. (2000). A brief history of memory research. In E. Tulving \& F. I. M. Craik (Ed.), The Oxford Handbook of Memory (s. 3-32). New York: Oxford University Press. 
Britt, D. M., Adams, S. G., Godding, P. R., Grothues, C. A., \& Varnado, P. (1995). Clinical differentiation of the Rey Auditory-Verbal Learning Test. American Journal of Alzheimer's Disease and Other Dementias, 10(6), 7-18. https://doi.org/10.1177/153331759501000603

Cavaco, S., Gonçalves, A., Pinto, C., Almeida, E., Gomes, F., Moreira, I., ... Teixeira-Pinto, A. (2015). Auditory Verbal Learning Test in a large nonclinical Portuguese population. Applied Neuropsychology: Adult, 22(5), 321-331. https://doi.org/10.1080/23279095.2014.927767

Cerami, C., Dubois, B., Boccardi, M., Monsch, A. U., Demonet, J. F., \& Cappa, S. F. (2017). Clinical validity of delayed recall tests as a gateway biomarker for Alzheimer's disease in the context of a structured 5-phase development framework. Neurobiology of Aging, 52, 153-166. https://doi.org/10.1016/j.neurobiolaging.2016.03.034

Claparède, É. (1919). Percentilage de quelques tests d'aptitude. Archives De Psychologie, 17, 313-324.

Červenková, M., Heissler, R., Georgi, H., \& Kopeček, M. (2018). Stability of SuperAgers over three years. In Proceedings of 5th Bordeaux Neurocampus Conference, Aging of memory functions: Where are we now? (s. 33). Bordeaux, France: Université de Bordeaux. Získáno z http://brainconf.u-bordeaux.fr/files/aging/abstractbook-aging-20180924.pdf

Ebbinghaus, H. (1885). Über das Gedächtnis. Untersuchungen zur experimentellen Psychologie. Leipzig: Duncker \& Humblot.

Estévez-González, A., Kulisevsky, J., Boltes, A., Otermín, P., \& García-Sánchez, C. (2003). Rey verbal learning test is a useful tool for differential diagnosis in the preclinical phase of Alzheimer's disease: comparison with mild cognitive impairment and normal aging. International Journal of Geriatric Psychiatry, 18(11), 1021-1028. https://doi.org/10.1002/gps.1010

Ferreira Correia, A., \& Campagna Osorio, I. (2014). The Rey Auditory Verbal Learning Test: normative data developed for the Venezuelan population. Archives of Clinical Neuropsychology, 29(2), 206-215. https://doi.org/10.1093/arclin/act070

Frydrychová, Z., Kopeček, M., Bezdíček, O., \& Štěpánková Georgi, H. (2018). České normy pro revidovaný Reyův auditorně-verbální test učení (RAVLT) pro populaci starších osob. Československá psychologie, 62(4), 330-349.

Griffin, J. W., John, S. E., Adams, J. W., Bussell, C. A., Saurman, J. L., \& Gavett, B. E. (2017). The effects of age on the learning and forgetting of primacy, middle, and recency components of a multi-trial word list. Journal of Clinical and Experimental Neuropsychology, 39(9), 900-912. https://doi.org/10.1080/13803395.2017.1278746

Harrison, T. M., Weintraub, S., Mesulam, M.-M., \& Rogalski, E. (2012). Superior memory and higher cortical volumes in unusually successful cognitive aging. Journal of the International Neuropsychological Society, 18(06), 1081-1085. https://doi.org/10.1017/S1355617712000847

Hess, H. N. (2007). Auditory Verbal Learning in schizophrenia: Patterns of memory retrieval (Disertační práce). Pacific Graduate School of Psychology.

Horáková, K., Štěpánková, H., Bezdíček, O., \& Kopeček, M. (2017). Kontrolované učení ve starším věku. Československá psychologie, 61(3), 213-229. 
Horáková, K., Štěpánková, H., Kopeček, M., \& Bezdíček, O. (2016). Konvergentní validita testu kontrolovaného učení s bezprostředním vybavením u zdravé starší populace. In H. Štěpánková \& R. Šlamberová (Eds.), Stárnutí 2016: Sborník př̌spěvků z 3. Gerontologické mezioborové konference (Roč. 3., s. 61-67). Praha: Univerzita Karlova, 3. lékařská fakulta.

KoKa - Kognitivní kalkulátor. (2018). (Verze 2.0) [Computer software]. Klecany: Národní ústav duševního zdraví. Získáno z http://www.nudz.cz/p_skupina/ps-geropsychologie/

Lezak, M. D., Howieson, D. B., Bigler, E. D., \& Tranel, D. (2012). Neuropsychological Assessment . Oxford, New York: Oxford University Press.

Lipmann, O. (1922). Handbuch psychologischer Hilfsmittel der psychiatrischen Diagnostik: Aus der Sammlung des Instituts für angewandte Psychologie und aus der Literatur. Leipzig: Johann Ambrosius Barth.

Messinis, L., Tsakona, I., Malefaki, S., \& Papathanasopoulos, P. (2007). Normative data and discriminant validity of Rey's Verbal Learning Test for the Greek adult population.

Archives of Clinical Neuropsychology, 22(6), 739-752.

https://doi.org/10.1016/j.acn.2007.06.002

Mitrushina, M. N., Boone, K. B., Razani, J., \& D'Elia, L. F. (2005). Handbook of normative data for neuropsychological assessment. New York: Oxford University Press.

Nikolai, T., Štěpánková, H., Vyhnálek, M., \& Kopeček, M. (2016). Neuropsychologická diagnostika kognitivního deficitu ve stáří. Československá psychologie, 60(5), 525-541.

Nikolai, T., Vyhnálek, M., Štěpánková, H., \& Horáková, K. (2013). Neuropsychologická diagnostika kognitivního deficitu u Alzheimerovy choroby. Psychiatrické centrum Praha.

Poreh, A., Sultan, A., \& Levin, J. (2012). The Rey Auditory Verbal Learning Test: Normative data for the Arabic-speaking population and analysis of the differential influence of demographic variables. Psychology \& Neuroscience, 5(1), 57-61.

https://doi.org/10.3922/j.psns.2012.1.08

Preiss, M. (1994). Klinické vyšetření paměti u dětí. Československá psychologie, 38(6), 545553.

Preiss, M., Bartoš, A., Čermáková, R., Nondek, M., Benešová, M., Rodriguez, M., ... Nikolai, T. (2012). Neuropsychologická baterie Psychiatrického centra Praha: klinické vyšetření základních kognitivnich funkcí. Praha: Psychiatrické centrum.

Preiss, M., Motejlková, J., Janů, I., \& Kolářová, E. (2001). Pamětový test učení: současné normy pro děti ve věku 9-14 let. Psychiatrie, 5(3), 156-160.

Rabin, L., Barr, W., \& Burton, L. (2005). Assessment practices of clinical neuropsychologists in the United States and Canada: A survey of INS, NAN, and APA Division 40 members. Archives of Clinical Neuropsychology, 20(1), 33-65.

https://doi.org/10.1016/j.acn.2004.02.005

Rey, A. (1958). L'examen clinique en psychologie. Boulevard Saint-German, Paris: Presses Universitaires de France.

Ricci, M., Graef, S., Blundo, C., \& Miller, L. A. (2012). Using the Rey Auditory Verbal Learning Test (RAVLT) to differentiate Alzheimer's dementia and behavioural variant fronto-temporal dementia. The Clinical Neuropsychologist, 26(6), 926-941. https://doi.org/10.1080/13854046.2012.704073

Schmidt, M. (2004). Rey Auditory Verbal Learning Test: A handbook. Los Angeles: Western Psychological Services. 
Stehlíková, J. (2018). Pamět’ový test učení - recenze metody. TESTFÓRUM, (11), 57-64. https://doi.org/10.5817/TF2018-11-206

Strauss, E., Sherman, E. M. S., Spreen, O., \& Spreen, O. (2006). A compendium of neuropsychological tests: administration, norms, and commentary. Oxford ; New York: Oxford University Press.

Taylor, E. M. (1959). Psychological appraisal of children with cerebral defects. Cambridge: Harvard University Press.

\section{Údaje o autorkách}

Mgr. Zuzana Frydrychová pracuje v Národním ústavu duševního zdraví v Pracovní skupině Geropsychologie a je doktorskou studentkou Klinické psychologie na Filozofické fakultě Univerzity Karlovy, její školitelkou je PhDr. Hana Georgi, Ph.D.

\section{Kontaktní údaje:}

Adresa: Národní ústav duševního zdraví, Topolová 748, 250 67, Klecany

E-mail: zuzana.frydrychova@ nudz.cz

PhDr. Hana Georgi, Ph.D. vede v Národním ústavu duševního zdraví Pracovní skupinu Geropsychologie. Je spoluzakladatelkou Sekce geropsychologie při Českomoravské psychologické společnosti a zástupkyní ČR v SC on GeroPsychology EFPA.

\section{Kontaktní údaje:}

Adresa: Národní ústav duševního zdraví, Topolová 748, 250 67, Klecany

E-mail: hana.georgi@nudz.cz

Frydrychová, Z., \& Georgi, H. (2019). Historie a současnost Reyova Auditorně-verbálního testu učení (RAVLT) v Česku. E-psychologie, 13(1), 48-59. https://doi.org./10.29364/epsy. 338 
Tabulka č. 2: Přehled verzí RAVLT - francouzská, anglická a české verze

\begin{tabular}{|c|c|c|c|c|c|c|c|c|c|}
\hline \multicolumn{5}{|c|}{ SEZNAM A } & \multicolumn{5}{|c|}{ SEZNAM B } \\
\hline $\begin{array}{l}\text { FR } \\
(1919)\end{array}$ & $\begin{array}{l}\text { ENG } \\
(2000)\end{array}$ & \begin{tabular}{|l|} 
ENG \\
$(1959)$
\end{tabular} & $\begin{array}{l}\mathrm{CZ} \\
(1994)\end{array}$ & $\begin{array}{l}\text { CZ } \\
(2014)\end{array}$ & \begin{tabular}{|l} 
FR \\
$(1919)$
\end{tabular} & \begin{tabular}{|l} 
ENG \\
$(2000)$
\end{tabular} & \begin{tabular}{|l} 
ENG \\
$(1959)$
\end{tabular} & \begin{tabular}{|l|}
$\mathrm{CZ}$ \\
$(\mathbf{1 9 9 4})$
\end{tabular} & \begin{tabular}{|l|}
$\mathbf{C Z}$ \\
$(\mathbf{2 0 1 4})$
\end{tabular} \\
\hline tambour & drum & drum & buben & buben & pupitre & desk & desk & stůl & stůl \\
\hline rideau & curtain & curtain & záclona & záclona & berger & shepherd & ranger & plavec & myslivec \\
\hline ceinture & belt & bell & zvonek & zvonek & moineau & sparrow & bird & pták & pták \\
\hline café & coffee & coffee & kafe & káva & soulier & shoe & shoe & bota & bota \\
\hline école & school & school & škola & škola & fourneau & stove & stove & kamna & kamna \\
\hline parent & parent & parent & rodiče & rodiče & montagne & mountain & mountain & hory & hora \\
\hline soleil & sun & moon & měsíc & měsíc & lunette & glasses & glasses & brýle & brýle \\
\hline jardin & garden & garden & zahrada & zahrada & éponge & sponge & towel & ručník & ručník \\
\hline casquette & cap & hat & klobouk & klobouk & nuage & cloud & cloud & mraky & mrak \\
\hline paysan & farmer & farmer & zemédělec & sedlák & bateau & boat & boat & lod' & lod' \\
\hline moustache & moustache & nose & nos & nos & mouton & sheep & lamb & jehně & jehně \\
\hline dindon & turkey (male) & turkey & Čína & husa & fusil & gun & gun & pistole & pistole \\
\hline couleur & color & color & barva & barva & crayon & \begin{tabular}{|l|} 
pencil \\
\end{tabular} & pencil & tužka & tužka \\
\hline maison & house & house & dům & dům & église & church & church & kostel & kostel \\
\hline rivière & river & river & řeka & řeka & poisson & fish & fish & ryba & ryba \\
\hline 2,27 & 1,6 & 1,53 & 2,20 & 2,07 & 2,27 & 1,33 & 1,33 & 1,93 & 1,86 \\
\hline \multicolumn{10}{|c|}{$\begin{array}{l}\text { Poznámky: FR (1919) - původní francouzská verze dle Claparède (1919); ENG (2000) - doslovný překlad francouzské verz } \\
\text { do angličtiny dle Boake (2000); ENG (1959) - anglická adaptace Edith M. Taylorové (1959); CZ (1994) - Pamět'ový test učení dl } \\
\text { Preisse (1994); CZ (2014) - Reyův auditorně-verbální test učení dle Bezdíčka, Štěpánkové a Nikolaie (2014c) }\end{array}$} \\
\hline
\end{tabular}

